\title{
Wheat Anaphylaxis due to Skin Contact in an Exclusively Breastfed 2.5-Month-Old Infant
}

Sadri $\mathrm{H}^{1,2}$, Fazlollahi MR ${ }^{2}$, Shokouhi Shoormasti $\mathrm{R}^{2}$, Pourpak $\mathrm{Z}^{2}$ ${ }^{1}$ Department of Allergy and Immunology, Emam Ali Hospital, Alborz University of Medical Sciences, Karaj, Iran ${ }^{2}$ Immunology, Asthma and Allergy Research Institute, Tehran University of Medical Sciences, Tehran, Iran

J Investig Allergol Clin Immunol 2019; Vol. 29(1): 62-64 doi: $10.18176 /$ jiaci.0332

Key words: Specific lgE. Wheat. Anaphylaxis. Skin contact.

Palabras clave: IgE específica. Trigo. Anafilaxia. Contacto cutáneo.

Anaphylactic reaction induced by contact between the skin and food allergens is rare in infants. To the best of our knowledge, there have been no reported cases of anaphylactic reaction following skin exposure to wheat in infants, although rare cases of anaphylaxis have been reported after skin contact with peanut, milk, egg, and fish [1]. We report a case of anaphylaxis resulting from skin contact with wheat in an infant.

A 2.5-month-old boy experienced generalized urticaria, breathing difficulty, lethargy, cyanosis around the mouth, acrocyanosis, and severe penis swelling about 5 minutes after contact of the penis with a mixture of wheat dough and animal fat. He was circumcised when he was 1 month old and had developed skin adhesions at the site. According to a traditional belief, this combination relieves skin adhesion and problems associated with circumcision. His parents washed his penis immediately after the anaphylactic reaction and went to the emergency department.

Following therapy with epinephrine, corticosteroids, and fluid resuscitation, he was referred to our hospital, where he was seen by an allergist-clinical immunologist.

The patient was born through cesarean delivery (birth weight, $3700 \mathrm{~g}$ ). Following umbilical cord separation on the eighth day after birth, the aforementioned mixture was placed on the site of umbilical cord. A few minutes later, he began to experience severe vomiting, although no redness was observed around the umbilical cord.

He was exclusively breastfed, and his mother was not on a specific diet. He has had recurrent vomiting and drooling since the neonatal period, suggesting a diagnosis of gastroesophageal reflux disease.

His mother had a history of allergic rhinitis, and his 3-yearold brother had experienced localized urticaria following an insect bite. A physical examination at 2.5 months of age revealed his weight to be $6 \mathrm{~kg}$, and the only positive finding was mild atopic dermatitis on the cheeks.

Three days after the diagnosis of anaphylaxis, the specific IgE concentration was measured using the RIDA qline Allergy test for food allergens (R-Biopharm) and ImmunoCAP 
(Thermo Fisher Scientific) for wheat and its allergens, including $\omega-5$ gliadin (rTri a 19) and lipid transfer protein (rTri a 14).

The RIDA qline Allergy test showed positive specific IgE only to wheat $(8.62 \mathrm{IU} / \mathrm{mL})$. In addition, the specific $\operatorname{IgE}$ concentration to wheat was $55.8 \mathrm{kU} / \mathrm{L}$ using ImmunoCAP. The results of the molecular diagnosis showed a specific $\operatorname{IgE}$ concentration of 1.88 and $<0.10 \mathrm{kU} / \mathrm{L}$ for $\omega-5$ gliadin and lipid transfer protein, respectively. Furthermore, specific IgE $(\mathrm{kU} / \mathrm{L})$ to other cereals was as follows: barley, 2.94 ; rice, $<0.10$; and maize, 0.17 . The white blood cell count was 7100 , the eosinophil percentage was $5.2 \%$, and total $\mathrm{IgE}$ was $139 \mathrm{IU} /$ $\mathrm{mL}$. The patient was prescribed avoidance of gluten-containing food and EpiPen for emergency situations.

At 4 months of age, the parents declared that the child had experienced severe vomiting after a short stop in front of a bakery.

The RIDA qline Allergy test was repeated with a food allergen panel at 4 months of age and revealed specific IgE to wheat $(0.34 \mathrm{IU} / \mathrm{mL})$. In addition, specific IgE to other allergens was negative. Specific IgE to wheat was also assessed using ImmunoCAP, although the concentration was significantly lower than the first time $(15.9 \mathrm{kU} / \mathrm{L})$.

Anaphylactic reactions have been reported in exclusively breastfed infants. These could be due to the transmission of food allergens from breast milk or exposure through skin or the respiratory tract [2].

Sporadic cases of anaphylactic reaction resulting from skin contact have been reported mainly in children with atopic dermatitis who come into contact with egg, milk, fish, and peanut [1]. All cases of wheat anaphylaxis, including those recorded in Iran, occurred after direct feeding with wheat [3].

Wheat products are usually introduced to infants at 4-6 months; however, allergic sensitization can occur before direct feeding of wheat via the passage of allergen from breast milk [4]. The failure to develop an anaphylactic reaction in spite of the transmission of wheat allergen from breast milk can result from allergen-immunoglobulin immune complexes in breast milk [5]. In addition, oral tolerance may be induced in infants through very low amounts of gluten in breast milk. It was recently suggested that skin contact with food proteins can bring about the penetration of food allergens through the disrupted skin barrier, for example, in atopic dermatitis. Presentation of an allergen to cutaneous Langerhans cells can result in the induction of $\mathrm{T}_{\mathrm{H}} 2$ responses and, subsequently, the production of allergen-specific IgE by B cells, while low transmission of food allergens in breast milk can induce oral tolerance [5].

According to this hypothesis, the anaphylactic reaction in the case we report could be attributed to contact with the wheat allergen at 8 days of age. However, the onset of severe vomiting after skin contact with wheat at the age of 8 days is still open to discussion. As a result, it seems that the patient had already been exposed to the wheat allergen and presentation of the allergen to the patient's immune system and sensitization occurred before 8 days of age, perhaps even in utero, as low quantities of allergen were detected in the placenta and cord blood in a study by Edelbauer et al [6].
It was recently suggested that wheat allergy, contact urticaria, and wheat-dependent exercise-induced anaphylaxis could develop in adults as a result of using soaps containing hydrolyzed wheat proteins $[4,7]$. However, this type of sensitization has not yet been reported in infants.

Two factors were involved in the onset of anaphylaxis after skin exposure in the present case. The first was the high concentration of specific IgE to the wheat allergen before age 3 months and the higher clinical relevance of lower levels of specific IgE at lower ages [8]. The other is that the wheat was raw (cooking can reduce its allergenicity) [9].

Specific IgE to barley was positive, possibly as a result of strong cross-reactivity between wheat and barley. Moreover, specific IgE to rice and maize was negative. This finding had been demonstrated in a previous study. Both rice and maize can be recommended as alternative cereals [10].

The RIDA qline Allergy test and ImmunoCAP were performed 3 and 45 days after the anaphylactic reaction. Specific IgE to wheat decreased rapidly after allergen avoidance. Therefore, it can be concluded that in vitro tests are most sensitive early after the anaphylactic reaction.

\section{Funding}

The authors declare that they did not receive funding for the present study.

\section{Conflicts of Interest}

The authors declare that they have no conflicts of interest.

\section{References}

1. Tan BM, Sher MR, Good RA, Bahna SL. Severe food allergies by skin contact. Ann Allergy Asthma Immunol. 2001;86(5):5836.

2. Lifschitz CH, Hawkins HK, Guerra C, Byrd N. Anaphylactic shock due to cow's milk protein hypersensitivity in a breastfed infant. J Pediatr Gastroenterol Nutr. 1988;7(1):141-4.

3. Pourpak Z, Ghojezadeh L, Mansouri M, Mozaffari $H$, Farhoudi $A$. Wheat anaphylaxis in children. Immunol Invest. 2007:36(2):175-82.

4. Quirce S, Boyano-Martinez T, Diaz-Perales A. Clinical presentation, allergens, and management of wheat allergy. Expert Rev Clin Immunol. 2016;12(5):563-72.

5. Lack G. Update on risk factors for food allergy. J Allergy Clin Immunol. 2012;129(5):1187-97.

6. Edelbauer M, Loibichler C, Nentwich I, Gerstmayr M, Urbanek $\mathrm{R}$, Szepfalusi Z. Maternally delivered nutritive allergens in cord blood and in placental tissue of term and preterm neonates. Clin Exp Allergy. 2004;34(2):189-93.

7. Scibilia J, Rossi CM, Losappio LM, Mirone C, Farioli L, Pravettoni $V$, et al. Wheat food allergy in adults has a favorable prognosis. J Investig Allergol Clin Immunol. 2018;29(2). In press.

8. Komata T, Soderstrom L, Borres MP, Tachimoto H, Ebisawa M. The predictive relationship of food-specific serum $\operatorname{lgE}$ concentrations to challenge outcomes for egg and milk varies by patient age. J Allergy Clin Immunol. 2007;119(5):1272-4. 
9. Varjonen E, Bjorksten F, Savolainen J. Stability of cereal allergens. Clin Exp Allergy. 1996;26(4):436-43.

10. Pourpak Z, Mesdaghi M, Mansouri M, Kazemnejad A, Toosi $S B$, Farhoudi A. Which cereal is a suitable substitute for wheat in children with wheat allergy? Pediatr Allergy Immunol. 2005; 16(3):262-6.

Manuscript received June 20, 2018; accepted for publication October 1, 2018.

Zahra Pourpak

Immunology, Asthma and Allergy Research Institute Tehran University of Medical Sciences P.O. BOX 14185-863, Tehran, Iran E-mail: pourpakz@sina.tums.ac.ir 